\title{
Storied Ground: Landscape and the Shaping of English National Identity
}

Review Number: 2299

Publish date: Thursday, 20 December, 2018

Author: Paul Readman

ISBN: 9781108424738

Date of Publication: 2018

Price: $£ 24.99$

Pages: 348pp.

Publisher: Cambridge University Press

Publisher url: http://www.cambridge.org/gb/academic/subjects/history/british-history-after-1450/storied-ground-lan and-shaping-english-national-identity?format=HB\#EtGjCMLvbJf94KZx.97

Place of Publication: Cambridge

Reviewer: Angus Winchester

This impressively researched and finely written study is an ambitious attempt to use the history of specific regions and localities to explore wider themes of national identity and attitudes to landscape and the environment across the long 19th century, from around 1780 to 1914. It thus marries the exploration of meaning in the landscape, pioneered by geographers since the 1970s, with the historical literature on nation and identity; the result is a lively and stimulating book, bursting with fresh insights into the relationship between people and landscapes. Paul Readman's focus is on the 'associational value' of landscape - the historical associations which, he argues, played a major part in how landscapes came to be viewed as expressions of national identity.

The book consists of six carefully crafted case studies, grouped in pairs to explore meaning in different types of landscape. The first pair, on the white cliffs of Dover and the borderlands of Northumberland, examines landscapes which defined the physical boundaries of the English nation. The second, on the contrasting environments of the Lake District and the New Forest, focuses on the contests which arose during the early days of the landscape preservation movement. The third, entitled 'Beyond the South Country', deliberately looks beyond the iconic rural scene to argue that urban landscapes also contributed to notions of national identity: the 'shock landscape' of industrial and commercial Manchester could be celebrated for its contribution to England's economic success; while the length of the Thames, encompassing both rural idyll and industrial grit, was also 'a source of patriotic pride on account of its wealth-creating role' (p. 253).

Each of these landscapes is thoroughly researched in a wide range of contemporary sources, as diverse as guidebooks and travel writing, popular literature, newspapers and magazines, parliamentary debates and official reports, paintings and engravings. As a result, each case study is soundly grounded in primary evidence. The author subjects all these sources to a penetrating and subtle analysis, reading them in depth for their cultural meaning.

The cliffs of Dover form the starting point, the obvious edge of England and perhaps the best-known point of arrival on its shores. Like the other landscapes discussed in the book, they possessed a range of meanings. 
As emblematic of the island nation, the walls of chalk symbolised England's separateness and difference from its continental neighbours; they could be seen as a symbol of 'national security and defiance' (p. 38). But, as point of arrival, they were also emblematic of home and homecoming, a reassurance of continuity in a rapidly changing world. In this respect the cliffs of Dover were part of a wider British identity, in contrast to the interior of Kent which was quintessentially English, as the 'garden of England'. The power of the cliffs as a symbol of national identity is illustrated by the furore over an advertisement for Quaker Oats plastered on the cliff face, which was condemned by local newspapers in 1901, not only as an eyesore but also because the cliffs of 'Old Albion' had been 'disfigured only to proclaim the virtues of Yankee oats' (quoted p. 46).

England's land border with the neighbouring kingdom of Scotland is the subject of the second chapter. This is a cold northern landscape infused with a history of warfare and Border hostility, 'a blood-soaked landscape ... powerfully evocative of centuries of conflict' (p. 59). The Border ballads helped to pin history to the landscape by linking specific events to particular places, so that place-specific stories were handed down the generations. However, by the later 19th century this bloody landscape had become a region of 'romance and valour' as the heroic exploits of both English and Scots were celebrated. When a monument was built to mark the site of the battle of Flodden in 1910, it was erected to the memory of 'the brave of both nations', demonstrating that by that date the Border landscape had become part of a common Anglo-Scottish heritage and hence a celebration of a British-Unionist sense of identity. The Border landscape thus celebrated a specific regional identity, very different from that of the rural 'south country': as Readman comments, we need to recognise a 'multiplicity of English identities', not just multiple British identities, within these islands.

The next two chapters focus on the preservation movement in landscapes which had come to be viewed as national treasures. The idea that the Lake District was, in Wordsworth's much-quoted phrase, 'a sort of national property, in which every man has a right and interest who has an eye to perceive and a heart to enjoy' is well known. Readman is able to demonstrate that the idea long predated Wordsworth: in 1772 William Gilpin had seen the owner of abbey ruins as merely their guardian for posterity, while Richard Warner, writing in 1802, called the Lake District's scenic attractions 'the common property of the people' (quoted p. 105). By the end of the 19th century, the notion of the Lake District as national property extended beyond its aesthetic and recreational value to the added associational value of its distinctive regional history. This lay in part in its literary associations but also (and of increasing importance) in its strong Scandinavian heritage. Thanks to the work of W. G. Collingwood and H. D. Rawnsley, the Norse blood in the native communities of the Lakes was used to celebrate a distinct regional identity in which 'ethnic intermixture [was seen] as a source of strength' (p. 143). Readman goes so far as to suggest that this pride in Norse heritage entered national conceptions of Englishness, by demonstrating 'the centrality of ethnic heterogeneity to English greatness'.

Debates over the preservation of the New Forest landscape reflected contested conceptions of the value of the former royal hunting ground to the nation as a whole. As Readman puts it, there were three New Forests in the 19th century: the Crown estate seen as vital for timber production in the nation's naval interest; the common lands, where deeply-rooted traditional use by the commoners continued to underpin the local economy, and the tourist honeypot, 'a place of sylvan beauty, primaeval wilderness, personal freedom and pleasure' which was 'freighted by associations with the past' (p. 155), not least as the site of the killing of William Rufus in 1100. The balance between these conceptions shifted across the century. The New Forest Act of 1877, which restricted the Crown's powers of enclosure, represented a victory for commons preservation over the earlier patriotic discourse of timber production and in so doing allowed the landscape of common land in the Forest to gain value as an expression of continuity with an English past. The commoners, the Forest's inhabitants, were no longer viewed as wild and backward but as possessing a 'virtuous independence' (p. 165) as survivors of an older, rural world of freeborn Englishmen and sturdy yeomen. The New Forest thus 'provided an important sense of continuity with the English past, so acting as an antidote to the identity-sapping anomie of urban-industrial modernity' (p. 175). 
That suggests that the rural landscape could be viewed primarily as a repository of nostalgic value. But the final two chapters seek to redress the balance by examining landscapes which were on the face of it landscapes of modernity. For all its industrial squalor, Manchester was celebrated in the mid-19th century as an urban landscape in the process of being transformed into a modern city. Factories had long been included on the tourist itinerary as curiosities, their sheer size, their cutting-edge technology and the 'flaring nocturnal light effects' (p. 206) of their rows of gas-lit windows all attracting visitors. As the town grew in wealth and sophistication, its warehouses and public buildings became sights to be seen: Manchester's landscape expressed progress and celebrated England's economic power and was valued as such. But modern Cottonopolis needed a past. By the later decades of the century, in Manchester as elsewhere, the local past was being used in the service of civic culture to celebrate modernity. Manchester and its surroundings contained tangible legacies of the past in the form of surviving black-and-white timber-framed buildings which formed the focal point for much of the celebration of the area's local history from the 1870s, providing 'storied' places for the town. Readman's reading of the 1887 Exhibition sees significance in the large part given to Tudor buildings there. Not only did the 'valorisation of a Tudor aesthetic' reflect a wish to 'bring the past into the service of the present, to frame the great advances of modernity' but the focus on the sixteenth century harked back to a people's past in 'Merrie England', appealing to a Manchester's 'burgeoning democratic sensibility' (pp. 237-8).

The final chapter, on the Thames, examines the subtleties of meaning with which the river and the riparian landscapes along its course were endowed across the nineteenth century. The Thames had long been celebrated as the source of London's wealth; across the nineteenth century, Readman argues, 'the symbolic force of the Thames ... owed most to its associations with the national past' (p. 251). He explores the changing conceptions of the Thames landscapes through the evolving use of the river, both up- and downstream from the capital, as a playground for Londoners. From the 1820s, the journey taken by excursionists downstream to Gravesend and Margate was punctuated by sites redolent of the nation's history: Greenwich Hospital; the royal dockyards at Woolwich, and Tilbury Fort. But it was the 'essentially English' landscapes of the Thames upstream from London which became the recreational focus in the later decades of the century, by which time the water of the Thames itself was claimed as a national property to which all should have freedom of access. Both upstream and downstream, the Thames was 'a potent symbol of the nation's past and its continuities; it was the history of England in landscape' (p. 299).

All six case studies are held together by a strong conceptual thread. Readman uses his detailed local research to offer a cogent thesis of the interplay between notions of Englishness and conceptions of landscape. His first theme is that, although the aesthetics played a part, it was the 'associational value' of landscapes, the way in which they were 'storied ground', bringing the visitor into contact with places connected with the past, which gave landscape its importance in ideas of national identity. It is worth noting that the focus is on the visitor's view (the 'tourist gaze'), for it is the meaning of landscapes to outsiders passing through that is central to the book's purpose, since visitors' perceptions both reflected the cultural norms of their times and were crucial in disseminating conceptions of landscape to a wider public. One of the strengths of the book is the clarity with which it traces the changing meanings attached to landscapes across long nineteenth century. Indeed, each case study shows how, by the increasingly urbanised and democratic society of the later nineteenth century, landscape had come to be viewed as a sort of national property, in which the people as a whole could claim an interest.

A second theme is that concepts of landscape as national heritage were complementary to ideas of progress and modernity and not, as has sometimes been claimed, essentially 'anti-modern, permeated by a reactionary, conservative-nostalgic mindset' (p. 15). The author sees expressions of patriotic discourse in responses to each of the landscapes studied in the book: the physical boundaries of the nation (at the white cliffs and on the Northumberland moors) helped define concepts of Englishness and of home. The battles for preservation in the treasured landscapes of the Lake District and the New Forest were infused with patriotic discourse. Nor was landscape as heritage confined to the countryside. The urban landscape of Manchester was celebrated not only as a beacon of economic success but as a local landscape rooted in a proud past. And 
the 'storied ground' of the landscapes traversed by the Thames, both up- and downstream from London, linked the bustling metropolis to the nation's wider history. Readman concludes, 'As reflected in and stimulated by engagement with valued landscapes both urban and rural, English cultural nationalism went with the grain of modernity, integrating the contemporary with the traditional, the past with the present' (p. 310).

To this reviewer, there was one missing ingredient in this otherwise rich and satisfying book. The author has chosen his case studies to make the point that a wide range of landscapes (coastal, riparian, upland, urban, industrial) were 'storied ground', capable of being used to foster aspects of national identity. As he notes on several occasions, in the background to these case studies lay the rural idyll of the English south country picturesque thatched cottages, rolling farmland and downland, and a stable social structure dominated by squire and parson. The absence of a full analysis of that archetypical landscape of Englishness is perhaps a weakness. It would have been welcome to have the 'chocolate box' English countryside subjected to the rigorous research and penetrating insight which characterise Paul Readman's analyses of the other landscapes discussed in this book.

\section{Other reviews:}

Times Higher Education https://www.timeshighereducation.com/books/review-storied-ground-paul-readman-cambridge-universitypress [2]

Source URL:https://reviews.history.ac.uk/review/2299

\section{Links}

[1] https://reviews.history.ac.uk/item/298770 [2] https://www.timeshighereducation.com/books/reviewstoried-ground-paul-readman-cambridge-university-press 